\title{
STREET-BASED CORRUPTION IN THE PHILIPPINES: EXPLORING KOTONG FRAME ALIGNMENTS BETWEEN ENFORCERS AND MOTORISTS IN A CITY IN METRO MANILA
}

\author{
Hannah Frances C. Bodegon* \\ Graduate Student, Political Science Department, \\ University of the Philippines Diliman, The Philippines \\ email: hannahcb_ph@yahoo.com \\ Prince Aian G. Villanueva** \\ Graduate Student, The Political Science Department, \\ De La Salle University Manila, The Philippines \\ email: prince_villanueva@dlsu.edu.ph \\ Janessa Polly J. Esber, Jon Christian A. Fernando, John Andrew \\ C. Guevarra and Charles Daniell B. Valeriano*** \\ Undergraduate Students, Political Science Program, \\ Colegio de San Juan de Letran, Manila, The Philippines
}

Published online: 15 July 2017

To cite this article: Bodegon, H. F. C. et al. 2017. Street-based corruption in the Philippines: Exploring kotong frame alignments between enforcers and motorists in a City in Metro Manila. International Journal of Asia Pacific Studies 13 (2): 93-113, https://doi.org/10.21315/ijaps2017.13.2.5

To link to this article: https://doi.org/10.21315/ijaps2017.13.2.5

\begin{abstract}
Corruption is a pervasive problem in the Philippines. Previous studies have focused on institutions and culture as factors behind the persistence of corruption in the country. Moreover, the emphasis has been on corruption that occurs within the bureaucracy. In this qualitative, exploratory study, we explored the possibility of the shared understanding, the frame alignments between the local state authorities and drivers as a possible explanation behind the persistence of street-based form of corruption known as kotongan or kotong. Based on the interviews conducted, results
\end{abstract}


showed that there is a shared understanding between state authorities and drivers as to what kotong is, the benefits they derive from the transaction, and the factors behind the acceptance of kotong.

Keywords: Frame alignments, kotong, kotongan, street-based corruption, corruption in the Philippines

\section{INTRODUCTION}

Recently, the New York Times declared the Philippines as the most corrupt country in Asia (Rodis 2015). This is not surprising as the history of the country abounds with news of corruption scandals that the national government has been embroiled in. For instance, in his short term as president, Estrada was involved in the Jueteng Scam, which led to the historical Epifanio de los Santos Avenue (EDSA) II, eventually resulting to him stepping down from position. Estrada's successor, President Arroyo and her husband were also involved in several corruption scandals that included the Fertiliser Scam, the Macapagal Boulevard Scandal, and the National Broadband Network (NBN)-ZTE Corporation (ZTE) Scandal. Under the recent administration, President Aquino who espoused the Daang Matuwid (Straight Path) policy, and several prominent senators including Senate President Juan Ponce Enrile, Senator Ramon "Bong" Revilla Jr. and Senator Juan "Jinggoy" Estrada were involved in the Napoles case. At the lower level, the news also trumpets stories regarding ordinary government officials accepting bribes in exchange for speedier transactions in an otherwise slow moving and bogged down Philippine bureaucracy. The news is also replete with stories of corruption that happens in the street, where police and traffic enforcers are alleged to have accepted a small amount of cash in exchange for turning a blind eye to traffic infractions committed. Thus, it seems that corruption in the Philippines is so pervasive that it encompasses the entire bureaucracy from the bottom to the top.

The Philippines is not the only country where corruption is an issue. Corruption is an endemic problem around the world (United Nations Convention Against Corruption 2004). For Transparency International, no one country in the world is corruption free. In fact, 68 percent of countries in the world are afflicted by corruption, including the G20 countries (Transparency International website). For Batalla (2000), corruption has been evident in the Philippines since the Spanish period and has since taken root in the society. This is despite the presence of laws and governmental bodies that aim to curb 
and eradicate corruption in the country. The 1987 Philippine Constitution itself provides that public office is public trust. Other laws related to graft and corruption include RA 6770 (The Ombudsman Act of 1989), RA 3019 (Anti-Graft and Corrupt Practices Act), RA 1379 (Forfeiture Law), Title Seven, Crimes Committed by Public Officers, Revised Penal Code, RA 6173 (Code of Conduct and Ethical Standards for Public Officials and Employees), RA 7080 (Plunder Act), Presidential Decree 46, Presidential Decree 749, Republic Act 9485 (Anti-Red Tape Act) and Republic Act 9160 (Anti-money Laundering). On the other hand, governmental bodies in charge with curbing and eradicating corruption include the Office of the Ombudsman, the Civil Service Commission, Commission on Audit, the Sandiganbayan, Department of Justice, National Bureau of Investigation, Philippine National Police, Presidential Commission on Good Government, Department of Finance, Revenue Integrity Protection Services, and the Anti-Money Laundering Council (Transparency and Accountability Network 2011).

There is no one definition of corruption. Transparency International defines it as "the abuse of entrusted power for private gains" (Transparency International website). Similarly, the World Bank defines corruption as the "abuse of public office for private gain" (World Bank website). The Asian Development Bank meanwhile locates corruption both in the public and the private sector and defines it as "the abuse of public or private office for personal gain" (Asian Development Bank website). Though corruption occurs in the private sector, corruption is more readily observed in the public sector. Corruption in the government has three broad layers: first, corruption within the broader political system that involves "the demands of electoral politics, the extensive use of patronage in political appointments, and the existence of pork barrel funds" (Balboa and Medalla 2006); second, corruption within the public sector that includes "spotty performance of mechanisms for identifying and sanctioning employees engaged in corrupt and illicit behaviour, considerations of pay and employment, and government procurement" (Balboa and Medalla 2006); and third, corruption within specific agencies, which covers "grand corruption (involving widespread syndicates and millions of pesos); and petty corruption (which involves smaller amounts of money, such as grease money to facilitate the delivery of goods and services)" (Balboa and Medalla 2006). Related to this is UNDP's two types of corruption, spontaneous and institutionalised. Spontaneous corruption occurs in societies with high morals in public service while institutionalised corruption has become a way of life given the pervasiveness of corruption in the society (Balboa and Medalla 2006). 
Of the layers of corruption in government, little attention has been paid to the phenomenon of street-based corruption in the Philippines. This is surprising given that street-based corruption is the most basic manifestation of corruption in the country. The Center for People Empowerment and Governance (CENPeg) recognises the importance of understanding streetbased corruption, and has since published a dictionary called "Corruptionary" (Jimenez 2010), a compilation of Filipino terms used for corruption that occurs in the street. Kotong or kotongan is one of the oft-used term that refers to the exchange of money between police officers and traffic aides and drivers who have disobeyed traffic laws. The creation of jargons on street-based corruption, and its penetration into the everyday vernacular of the Filipinos highlights the pervasiveness of street-based corruption in the Philippines. If this is the case, what could account for the pervasiveness of street-based corruption, specifically, kotong or kotongan in the Philippines? This is the main question that this study aims to answer. This study argues that there is an alignment of frames between the traffic enforcers and drivers on the notion of corruption, the benefits derived from the illicit exchange of money, and the causes of the persistence of kotong. This study argues that a possible explanation for the persistence street-based corruption in the Philippines, are the shared understandings between the legal authority and the citizen-drivers.

This paper is as organised as follows. First, we provide a brief review of existing literature on studies on corruption, proceeded by an examination of the literature on street-based corruption where we find out that very little thus far has been written on this form of corruption. Second, we establish the guiding frameworks: constructivism and interpretivism and frame alignment and how these frameworks are used in the study. Third, we establish the methodology used in this qualitative study. Fourth, we go into the results and analysis part. Fifth, we analyse the implications of the results of the study in the hope of eradicating corruption from the Philippine society, and recommend suggestions as to what else can be done in order to extend the study.

\section{REVIEW OF RELATED LITERATURE}

\section{Studies on Corruption}

Much has been written on the subject of corruption, on its meaning, the negative impacts on the political and economic development of states, and the causes for its persistence. This is especially so after the international recognition conferred upon it by the passing of international conventions such 
as the Organization for Economic Cooperation and Development (OECD) Convention on Combating Bribery of Foreign Public Officials in International Business Transactions, in 1997 (Rushton 2011) and the United Nations Convention Against Corruption in 2003 (United Nations Convention Against Corruption 2004). In effect, the passing of such conventions put corruption as an agenda to be resolved at the level of the state and through cooperative pursuits among the states, international institutions, and the civil society.

A review of the extant literature shows that many of the studies explore the relationship between institutions and corruption and culture and corruption. We first examine institutions and then proceed to culture. Institutions are defined in the traditional sense as "the formal rules and organisations" (Lowndes 2010: 60 ). The focus then is on the arrangement of the institutions and the formal rules and regulations that bound the organisation and the people in it. Later on, the definition of institutions under new institutionalism had come to include conventions and norms constructed by the members, which regulate their interaction with each other. However, a survey of the literature shows that studies on corruption and institutions view institutions in the more traditional sense. Specifically, these studies inquire as to which types, and permutations of institutions, do low levels of corruption persists; unitary vs. federal form of government; parliamentary vs. presidential form of government (Gerring and Thacker 2004); an open and transparent democratic form of government (Alt and Lassen 2003); the extent of freedom of press (Lederman, Loayza and Soares 2005; Treisman 2007); electoral rules and constitutional structures (Kunicova and Ackerman 2005); strong rule of law and established politicallegal structures (Zhan 2012); and the design and structure of government institutions and political processes (Shleifer and Vishny 1993). A few of the literature also examine how institutions can contribute to the pervasiveness of corruption. For instance, Yadav (2012) argues that legislative institutions, its rules and regulations can contribute to corruption. Ionescu (2011) for his part explores how the federal form of government contributes to the persistence of corruption in Mexico.

To some extent, also explored in the literature is the link between culture and corruption. Culture is defined as the "values and attitudes that guide a population" (Landes 2000: 2). In a compendium, Harrison and Huntington (2000) emphasise the import of culture in the course of human progress as for them, values matter! Indeed values matter as several authors have examined the relationship between the value of collectivity and corruption (Husted 1999; Soleim and Bontis 2009). The relationship between political culture and corruption is mostly examined in Asian states (Chang and Chu 
2006). This appears to be especially true in the Philippines. For example, Co (2005) and Jimenez (2010) aver that corruption is sustained by the culture of gift-giving, reciprocity and clientelism. Gift giving is related to the value of kindness, reciprocity meanwhile is related to the value of hiya (shame) or utang-na-loob (debt of gratitude). Clientelism refers to an asymmetrical relationship between two individuals where one acts as a patron and one acts as a client. In a similar discussion of elements in the Philippines that underlie Filipino values, Varela (2003) asserts that there are elements: personalism, familism, and particularism or popularism. Personalism is explained as the extent of importance Filipinos face on interpersonal relations. Familism meanwhile is related to the high value placed by Filipinos on the welfare of their own families in relation to the welfare of the community. Particularism or popularism pertains to the importance placed by Filipinos on being held in a high esteem by the members of the community. These three elements underlie the transactions of Filipinos with each other. Adding to the values already enumerated by Co (2005), Varela (2003) adds that Filipinos also hold the values of amor propio (honour), delicadeza (propriety), and pakikisama (getting along). These elements plus the values undergird the daily interaction of Filipinos. Quah (2010) agrees with Co (2005) and Varela (2003) and cites the same values as one of the culprits behind the persistence of corruption in the Philippines.

Evidently, much of the literature have focused on the macro level, focusing on the relationship between corruption and institutions, and corruption and the larger culture, whether as solution or contributing factor. However, a noteworthy investigation would also be at the level of the individual and the interaction between individuals and how it contributes to the persistence of corruption. This is where the present study comes in. In exploring the frame alignments on corruption between the local state authorities and public utility drivers, the spotlight is shifted to the individual's agency in the prevalence and persistence of corruption.

\section{Street-based Corruption}

Many articles are focused on petty corruption, a transaction that takes place between citizens and ordinary government employees. Though petty corruption occurs at a lower level in the government, it is a form of corruption that still occurs within the bounds of the bureaucracy (Lambert-Mogiliansky, Majumdar and Radner 2007; Adzanela 2012; Jancsics 2013). Surprisingly, very little has been written about corruption that takes place in the street regardless 
of the fact that news abound with stories of such form of corruption. In their study, Nieuwbeerta, De Geest and Siegers (2003) compared street-level corruption between industrialised and developing countries and they found out that countries with (1) high levels of economic development; (2) high levels of economic freedom; (3) long exposure to democracy; (4) non-federal structure; (5) Protestant traditions; and (6) British legal culture, experience lower levels of street-based corruption. Though groundbreaking, the use of quantitative method in this study loses the narratives of the parties that transact in corruption. In the Philippines setting, an example of a study on street-based corruption is that of Nolasco et al.'s (2014) qualitative study that examines the persistence of street based corruption kotongan in the Philippines by examining the ethical conundrum and motivations that bus and jeepney drivers faced in their decision-making to pay bribe or kotong to local state authorities. Jimenez's (2010) study on corruption focused on what she calls "corruption speak." In this study, she interviewed public utility vehicle drivers in order to understand the creation of corruption jargons in the country. These qualitative studies provided a good context by examining the experiences of public utility drivers. However, as petty corruption is a transaction between the local authorities and the drivers, it is noteworthy to examine where the ideas of the two parties align as to what street based corruption is and why does it persist. This is where the present study comes in.

\section{Theoretical Framework}

This study is anchored on the ideas of frame alignment, which is subsumed under the constructivist/interpretive theory. Onuf's words best explains what the constructivist/interpretive theory is about, when he said that "we inhabit a world of our own making" (cited in Parsons 2010: 80). This theory largely challenges the positivist/realist notion that knowledge is objective. For the constructivists, knowledge is the by-product of the daily interaction among individuals - that concepts only gain significance based on the negotiated meanings, called social constructs, which people attached to them. For Parsons (2010) and Benford (1997), these social constructs govern the action of people as "meaning is prefatory to action" (Benford 1997: 410), these meanings govern the way people "organise their identities, their relationships, and environment" (Parsons 2010: 80). Given this framework, street-based corruption, specifically kotong acquires meaning based on the face-to-face interaction between the local authorities, the Manila enforcers and the public utility drivers. 
Subsumed within the constructivist/interpretive theory is the frame alignment theory. The concept of frame first came from Erving Goffman who defined it in a functional manner as schemata of interpretation that "allow its users to locate, perceive, identify, and label a seemingly infinite number of concrete occurrences defined in its terms" (1974: 21). For Benford and Snow, "frames help to render events or occurrences meaningful and thereby function to organise experience and guide action" (2000: 614). In essence, frames are the shared understandings that help guide men in understanding their relationship with each other and their understanding of the society, which they are a part of. According to Gamson and Meyer (1996), the theory seeks to bring culture back in, as it posits that frames produced are bounded by the larger culture in which they are embedded. Framing, the verb used by Benford and Snow (2000) to refer to the process of creating frames spans a broad process that includes frame alignment. What is frame alignment?

Frame alignment within the literature of social movement refers to the "linkage of individual and SMO interpretive orientations, such that some set of individual interests, values, and beliefs and SMO activities, goal, and ideology are congruent and complementary" (Snow et al. 1986). The literature on social movements and framing is replete with studies that examine frame alignment as a factor behind the consequence of social movements (Benford and Snow 2000; Snow et al. 1986; Coley 2015; Katelaars et al. 2014). In such studies, scholars explore the existence of congruence between the movements' messages and the participation of people in social movements and how this critically affects the success or failure of social movements. Frame alignment is also examined in the field of media and communication where the literature explores the congruence between the information put out there by media - whether it be on print or television, with the larger opinion of the public. (Druckman 2001; Chong and Druckman 2007; Sanpei and AoyagiUsui 2009; Benelli 2003). Scholarly works on frame alignment in this field are interested in the link between media frame, which is a "central organising idea or story line that provides meaning to an unfolding strip of events" (Scheufele 1999: 106) and individual frame that is defined as "mentally stored clusters of ideas that guide individuals' processing of information" (Entman cited in Scheufele 1999:107). Regardless of what field, the essence of frame alignment theory is the emphasis on the shared meanings that guide action. In Political Science and Sociology that examine social movements, the focus is on shared meanings that lead to collective action efforts; in Media and Communication that focus on the importance of media, the stress is on shared meanings that affect the perception and attitude of the public on a variety of issues. 
Nevertheless, the emphasis is on how negotiated meanings between a group and individuals govern their action. Guided by the ideas of constructivism and frame alignment, we posit that the persistence of kotong, is a by-product of the shared meanings, between the local authorities, the Manila traffic enforcers, which are vested with the power to apprehend those who disobey the traffic laws in the Manila area, and the drivers, on what kotong is, and the mutual benefits that the parties derived from engaging in this street-based form of corruption.

\section{METHOD}

This is a qualitative, exploratory study. The qualitative approach is employed as it allows for a thicker description of the phenomena being studied. This study is exploratory in that it does not claim that the frame alignments on corruption between the state authorities and the drivers is the sole factor that explains the persistence of the phenomenon in the Philippines but merely explores the viability of frame alignments in examining corruption in the country. The researchers randomly interviewed eight traffic enforcers and eight drivers, 16 total, for a balanced narrative in a city in Metro Manila. The researchers also culled secondary data particularly journal articles and books that examine corruption in the Philippines to validate the narratives of the respondents. Content analysis was employed in processing the data gathered by the researchers.

\section{RESULTS AND ANALYSIS}

\section{Notions of Corruption}

\section{Congruence in notion of kotong as a monetary transaction}

There appears to be similarities in the understanding of both enforcers and motorists of kotong as a monetary transaction. This is manifested in the codes, signs and symbols that they use. For instance, according to Jimenez (2010), both the traffic enforcers and the public utility vehicle drivers use coded words in their transaction with each other. In an interview with public utility vehicle drivers, her study shows that local state authorities use phrases such as kilala mo ba si Osmeña (Do you know who Osmeña is?) or o sige baka mahuli ka nyan Ube na lang (You might be caught. But okay, ube will do). In situations 
where the drivers cannot yet pay for the amount asked of them by the enforcers, they will offer a counteroffer with a similar code such as, sir pula pula na lang ho, mahina pa eh (Sir, I'll just give pula-pula. I don't have enough earnings yet). The words, Osmeña, ube, and pula-pula are codes that denote the colour of Philippine paper bills and thus the amount of money that the transaction will cost the drivers caught committing traffic violations.

Aside from the coded words, there are also signs that both the local state authorities and drivers understand that kotongan is about to occur. This is manifested in the responses of the interviewees:

Motorist 5 averred, "Enforcers would motion to me to follow them to a more private spot after collecting my license and then would show me the amount of fine to be paid for each violation and proclaim that I would have to attend a seminar."

Motorist 2 said that, "They would flag me down, direct me to a more secluded spot and would ask me what I want to do regarding my traffic violation... that is when I know what they want me to do."

Enforcer 1 averred, "Enforcers will not directly ask for money as it is against the law, however, they will inform the violators of the amount of fine, for example saying that so and so violation is worth 2,000 pesos and that they will have to attend a seminar, when in reality, we do not really conduct seminars, we also tell them that it will take a while for them to get their license, in essence, what we want them to do is to read between the lines, by saying that, we want them to just give us some money, as we have already dropped several hints."

Enforcer 8 said that, "I flag down the motorist, get their license, direct them to a spot not seen by many, I look around if anyone is watching us and if I see that there is none, I will usually ask the driver what he plans to do about his violation, that is the clue I give to the driver."

By using these codes, signs and symbols, both the local authorities and motorists are able to make sense of what kotong is and how to interact with each other in such situations. Such shorthand allows both parties to navigate and circumvent the laws set forth for traffic violation. The regular usage of shorthand also seemingly makes it appear that kotong or kotongan has become a way of life in the Philippine society. It also reveals the shockingly lack of information on the part of the motorists regarding the traffic rules and regulations, including the most typical offenses committed by motorists. For instance, swerving, an oft-cited violation is not actually a traffic violation and 
does not necessitate the confiscation of the motorist's driver's license (mmda. gov.ph) - an example from the MMDA website is retained as the transaction is obviously a consequence of the lack of information on the part of the motorists as to what acts are considered violations.

\section{Congruence in notion of kotong as beneficial}

Seemingly, the motorists and enforcers are in agreement when it comes to the benefits that each party derives from such transaction. Responses show that benefits are of two kinds. The first kind pertains to the monetary benefit that each party receives. On the part of the enforcers, the kotong money serves to augment the meager salary that they receive every payday. On the side of the motorists, the heavy penalty imposed on traffic violations move them to pay the kotong money, which is significantly lesser, usually priced at 200-500 pesos. This is seen in the statements of the respondents.

Motorist 3 responded, "Well, they get more money they can use to provide for their family needs."

Motorist 6 said, "Maybe they need money, a lot of people need money."

Enforcer 3 said, "Maybe the enforcers are tempted to accept money due to the low salary that they receive."

Enforcer 5 responded, "It all comes down to needs, as people have many needs, they want to earn more, they want easy money as they have needs, and many expenses."

The second kind of benefit pertains to the saved up time and effort brought on by the transaction. On the side of the enforcers, the time and effort saved in surrendering the licenses collected to their proper offices. For the working motorists, the time and effort saved on commuting to city halls and to the land transportation offices to reclaim their licenses, which would entail taking precious time off from work, moves them to pay the kotong money to the enforcers.

Enforcer 7 averred that, "First, if they go to City Hall, they will pay a high amount, for instance 500 to 1000 pesos, second, for those who work, they do not want to take the time off, so they choose to pay, third, in general Filipinos do not want the hassle if they can settle things more easily, by paying the enforcers." 
Enforcer 4 said that, "It is easier to just pay us, because Filipinos would rather hand the money to us and save time and effort."

Motorist 1 pointed, "For motorists who are busy they opt to give money to the traffic enforcers once they get caught for committing traffic violations. First, I guess it is much cheaper and second I think it would take up much of their time to go to the responsible government agency in order to get their licenses."

Motorist 7 averred, "Considering the difficulties of claiming the license here in the Philippines, paying kotong is easier."

The amount of money and effort saved by paying kotong is confirmed by the data on traffic violations and fines under Joint Administrative Order No 201401 entitled Revised Schedule of Fines and Penalties for Violations of Laws, Rules, and Regulations Governing Land Transport. The table below shows the amount of fine and penalty for the typical traffic violation.

\section{Violation}

Fines and penalty

Driving without a valid driver's license/ 3000.00 pesos

conductor's permit.

In addition, the unlicensed or improperly licensed driver shall be disqualified from being granted a driver's license and driving a motor vehicle for a period of one year following the payment of fine.

Reckless driving defined as operating 1st offense $-2,000.00$ pesos

recklessly without reasonable caution 2 nd offense $-3,000.00$ pesos

in considering the width, traffic, grades, 3rd offense $-10,000.00$ pesos

crossing, curvatures, visibility and other conditions of the highway and the conditions of the atmosphere and the weather or so to endanger the property or the safety or rights of any person or so as to cause excessive or unreasonable damage to the highway. This includes driving an unregistered vehicle.

In addition:

Suspension of license for 3 months for the 2nd offense and 6 months for the 3rd offense from the payment of fine and revocation of driver's license on the succeeding offense.

A revoked non-professional driver's license shall be disqualified from being granted a driver's license for a period of two years from date of revocation.

Failure to wear the prescribed seat belt device.

1 st offense $-1,000.00$ pesos

2nd offense $-2,000.00$ pesos

3rd offense $-5,000.00$ pesos

In addition:

After 3rd and succeeding offense, suspension of license for 1 week from the payment of the fine. 
Table (continued)

\begin{tabular}{|c|c|}
\hline Violation & Fines and penalty \\
\hline $\begin{array}{l}\text { Failure to require his or her passengers to } \\
\text { wear the prescribed seat belt device. }\end{array}$ & $\begin{array}{l}\text { For PUVs and Operators, this will cost } 3,000.00 \\
\text { pesos }\end{array}$ \\
\hline $\begin{array}{l}\text { Failure to wear the standard protective } \\
\text { motorcycle helmet or failure to require the } \\
\text { backrider to wear the standard protective } \\
\text { motorcycle helmet under RA } 10054 \text {. }\end{array}$ & $\begin{array}{l}\text { 1st offense }-1,500.00 \text { pesos } \\
\text { 2nd offense }-3,000.00 \text { pesos } \\
\text { 3rd offense }-5,000.00 \text { pesos } \\
\text { 4th and succeeding offense }-10,000.00 \text { pesos }\end{array}$ \\
\hline $\begin{array}{l}\text { Failure to carry driver's license, certification } \\
\text { of registration or official receipt while driving } \\
\text { a motor vehicle. }\end{array}$ & $1,000.00$ pesos \\
\hline
\end{tabular}

All other violations of traffic rules and 1,000.00 pesos regulations which includes the following:

- Parking in an intersection, within 5 metres of the intersection, 4 metres from a fire hydrant, in front of a private driveway, on the roadside of any unmoving or parked MV at the curb or edge of the highway, at any place where signs of prohibition have been installed

- Disregarding traffic signs

- Allowing passengers or top or cover of a motor vehicle except in a truck helper

- Failure to provide canvass cover to cargos or freight of trucks requiring the same

- Permitting passengers to ride on moving board, stepboard, or mudguard of MV while the same is in motion

- Failure to dim headlights when approaching another motor vehicle

- Driving in a place not intended for traffic or into a place not allowed for parking

- Hitching or permitting a person or a bicycle, motorcycle, tricycle or skate roller to hitch to a motor vehicle

- Driving against traffic

- Illegal turn

- Illegal overtaking

- Overtaking at unsafe distance

- Cutting an overtaking driver

- Failure to give way to an overtaking vehicle which gave the proper signals

- Increasing speed when being overtaken

- Overtaking when left side is not visible

- Overtaking upon a crest of grade 


\section{Table (continued)}

\begin{tabular}{|c|c|}
\hline Violation & Fines and penalty \\
\hline $\begin{array}{l}\text { - Overtaking upon a curve } \\
\text { - Overtaking at any railway grade crossing } \\
\text { - Overtaking in an intersection } \\
\text { - Overtaking on men working or caution } \\
\text { signs } \\
\text { - Overtaking at no overtaking zones } \\
\text { - Failure to yield the right of way } \\
\text { - Failure to stop before traversing a } \\
\text { - Forough highway } \\
\text { - } \text { pailure to yield right of way to ambulance, } \\
\text { - Failure to give proper signals } \\
\text { Failure to stop motor and notch handbrake } \\
\text { - Un MV when unattended } \\
\text { - Obstruction towing }\end{array}$ & \\
\hline \multirow[t]{3}{*}{$\begin{array}{l}\text { Driving a motor vehicle under the influence } \\
\text { of alcohol/dangerous drugs/and or similar } \\
\text { substance upon final conviction by a regular } \\
\text { court of competent jurisdiction (Sec } 12 \text {, RA } \\
\text { 10586). }\end{array}$} & $\begin{array}{l}\text { In addition to the fines and penalties imposed by } \\
\text { the law. } \\
\text { The non-professional driver's license shall be } \\
\text { confiscated and suspended for a period of } 12 \text { mos. } \\
\text { for the first conviction and perpetually revoked } \\
\text { for the second conviction. }\end{array}$ \\
\hline & $\begin{array}{l}\text { The professional driver's license shall be } \\
\text { confiscated and perpetually revoked for the first } \\
\text { conviction. }\end{array}$ \\
\hline & $\begin{array}{l}\text { The perpetual revocation disqualifies the driver } \\
\text { from being granted any form of driver's license. }\end{array}$ \\
\hline
\end{tabular}

Source: Metro Manila Development Authority, www.mmda.gov.ph

As stated in the theory, frames are bounded by the culture in which they are created. The alignment in terms of benefits appears to be consistent with the culture of reciprocity in the Philippines. As stated by Co (2005), Filipinos are bounded by the culture of reciprocity related to the values of hiya (shame) or utang-na-loob (debt of gratitude). In the case of the drivers and local state authorities, the payment of the money is in a sense a debt of gratitude expressed by the apprehended drivers to the local state authorities for letting them off easily for the violation committed and sparing them the hassle of going through the process of collecting their licenses. The culture of clientelism also appears to underlie such transactions where the local state authorities and the apprehended drivers are both patrons and clients at the same time. Interestingly enough, in this case they are patrons and clients at the same time, 
for each party has something that the other needs and can give. On one hand, for the local state authorities, they can let the driver go (what they have to offer) in exchange for a certain amount (what they need), on the other hand, for the drivers, they want to get off easily for traffic violation committed (what they need) by paying the local state authorities a certain amount (what they have to offer). Thus, the transaction that occurs is beneficial for both parties, in effect a win-win situation for them.

\section{Factors behind the persistence of kotong}

Both the enforcers and the motorists are somewhat in agreement regarding the low salary received by enforcers and the need to provide for their families are two factors behind the pervasiveness of street-based corruption in the country. This is manifested in the statements of the interviewees:

Motorist 8 said that, "Well they get more money they can use to provide for their family's needs."

Motorist 4 averred, "I can't think of any other reason aside from money as these traffic enforcers receive lower salaries, they need the extra money to provide for their families."

Enforcer 2 said that, "It's due to poverty, imagine we only get 4,000 pesos a month, now if you are a family man, its really not enough to provide for your family, and most of us have families, that is why we are tempted to accept the money, at least I get to help my fellowmen and at the same time earn some extra money."

Enforcer 6 averred that, "For the family, for example my children is sick or they need allowance for school, the salary is not enough and that is why I am tempted to accept the money offered by the driver."

This is confirmed by the data provided in Senate Bill 391. In the 13th Congress, Senator Manuel Roxas III introduced Senate Bill 391 also known as A Resolution Directing the Appropriate Senate Committee to Conduct an Inquiry in Aid of Legislation, Into the Improved Implementation of the Unified Vehicular Volume Reduction Program and Other Transport and Traffic Regulation Schemes Implemented by the Metro Manila Development Authority. This resolution recognised the important role performed by traffic enforcers in regulating the traffic flow in an otherwise decongested Metro Manila roads. This bill proposed an increase in the salary of the enforcers, who received a gross monthly salary of 9,000 plus the 20 percent that they 
receive from the fines of traffic violations they apprehend and report. The bill argued that given the important role that the enforcers play in helping alleviate the issue of traffic, that their average daily wage of 288 to 370 pesos should be increased. Thus far, a law increasing the salary of the enforcers has not been passed, and no increase on their salaries have been given. The measly pay received by the enforcers vis-a-vis the daily cost of living in the Philippines serves as a strong motivation for them to solicit and accept the money offered by motorists in exchange for looking the other way when traffic violations have been committed.

From the above statements, both the traffic enforcers and the drivers are in agreement that the low salary and the need to provide for family are interrelated factors behind the acceptance of kotong money by the state authorities. In his own study, Quah (2010) agrees that the meagre salaries received by local state authorities are one of the reasons behind the pervasiveness of corruption. According to him, in a survey of public attitude towards corruption in the country conducted in 1998, low salary was cited as the major cause of corruption (Quah 2010: 11). Similar to the notion of benefits, Filipino values underlie the cause for kotongan. As mentioned above, Filipinos place a high value on families-familism. The desire to provide for the wants and needs of their families is a strong driving force behind the acceptance of kotong money. Both Quah (2010) and Jimenez (2010) affirmed this finding in their own studies on the persistence of corruption in the Philippines. The importance of the family is at the centre of the motivation to accept kotong money regardless of the possible consequences, particularly the loss of job, once apprehended by higher authorities. This also highlights the government's culpability in the pervasiveness of corruption, as they do not pay wages enough for their employees to stay true to their jobs without being tempted to compromise their principles. For Quah (2010), even the top officials are tempted given the salaries they receive.

\section{CONCLUSION}

Corruption is a perennial problem the Philippines faces. At the onset, the goal of this paper is to understand why street-based corruption continues to persist in the Philippines. As noted earlier, the literature has emphasised the import of institutions and the larger culture in relation to corruption. However, what this study showed is that the individual can also be a factor behind the problem of 
corruption in the country. Results of the study showed that the pervasiveness of street-based corruption is a consequence of the frame alignments between the local state authorities and the motorists. The shared understandings between the two parties serve to reinforce the kotongan, seemingly making it a way of life in the country. The negotiated meanings between them on what kotong is, the benefits derived from it, and the factors behind the payment of kotong serve to more deeply cement this form of corruption in the Philippine society.

Is there hope then for the Philippines ever eradicating corruption in the country? As this study showed, perception of corruption starts at the level of the individual, thus it is imperative to start at this level all the way to the top. What does this mean for the corruption policies of the government? The policies on corruption have been centered on reforming the institutions and creating new institutions to combat corruption in the country. However, the results of this study show that the government must focus on helping their citizens redefine corruption. This would entail more than its normative provision of values education for both primary and secondary students. Furthermore, this also highlights the need to strengthen the courses that deal with politics and governance, in all levels of education. The same is true at the level of informal education. The government's and the civil society's campaign to eradicate variants of corruption need to be strengthened as well. As what was found out, the propensity to engage in kotong by both the motorists and enforces is strong apparently due to the short-term benefits derived from the transaction. The need to highlight the long-term consequences of the types of corruption then in the information campaign is vital.

Kotong is only one of the perennial corruption problems the Philippines faces. While the current study adds to the very few thick descriptions of the problem, the study is limited in a number of respects. While the study looked at the corruption problem at the individual level, it may also be material to replicate it in other parts of the country to test if these alignments only exist in the metropolitan areas or if these transpire across the Philippines. Similarly, the study did not look at the impacts of kotong to the economy, polity and society, and this direction is important as well in understanding further the problem. Apparently, an attempt to further understand the issue means to provide concrete policy recommendations to address kotong and the study falls short in this respect. The study attempted to understand corruption at the level of the individual and as such, any attempt to look at bureaucratic reengineering from the level of the individual, may prove to be novel, as well. 


\section{NOTES}

* Hannah Frances C. Bodegon is a graduate student at the Commission on Higher Education (CHED) Center of Excellence for Political Science, Department of Political Science, University of the Philippines Diliman. Her research interests are on statesociety relations, social movements and corruption.

** Prince Aian G. Villanueva earned his Master of Arts in Political Science at the Commission on Higher Education (CHED) Center of Development for Political Science, The Department of Political Science, De La Salle University, Manila, The Philippines. He has published research in politics in national and international refereed journals. His research interests include corruption, e-governance and state-society relations.

*** Janessa Polly J. Esber, Jon Christian A. Fernando, John Andrew C. Guevarra and Charles Daniel B. Valeriano are undergraduate students of Political Science at Colegio de San Juan de Letran, Manila, The Philippines.

\section{REFERENCES}

Adzanela, A. 2012. Petty corruption and human rights implications - The case of Bosnia and Herzegovina. International Journal of Rule of Law, Transitional Justice and Human Rights 2 (2): 183-195.

Alt, J. E. and Lassen, D. D. 2003. The political economy of institutions and corruption in American states. Journal of Theoretical Politics 15: 341-365, https://doi.org/10.11 77/0951692803015003006.

Asian Development Bank. 2015. Anti-corruption policy. Asian Development Bank, http:// www.adb.org/documents/anticorruption-policy (accessed 24 August 2015).

Balboa, J. and Medalla, E. 2006. Anti-corruption and governance: The Philippine experience. Paper presented at APEC Study Center Consortium Conference, Ho Chi Minh City Vietnam, 23-24 May, http://www.apec.org.au/docs/06ascc_hcmc/06_9_1_balboa. pdf

Batalla, E. C. 2000. De-institutionalizing corruption in the Philippines: Identifying strategic requirements for re-inventing institutions. Paper presented at conference by Konrad Adenauer Stiftung (KAS) and De La Salle University - Yuchengco Center for East Asia (DLSU-YCEA), Makati.

Benelli, A. 2003. The role of media in steering public opinion on health issues. Health Policy 63: 179-186, https://doi.org/10.1016/S0168-8510(02)00064-7.

Benford, R. 1997. An insider's critique of the social movement framing perspective. Sociological Inquiry 67: 409-430, https://doi.org/10.1111/j.1475-682X.1997. tb00445.x.

Benford, R. D. and Snow, D. A. 2000. Framing processes and social movements: An overview and assessment. Annual Review of Sociology 26: 611-634, https://doi. org/10.1146/annurev.soc.26.1.611.

Chang, E. C. and Chu, Y. 2006. Corruption and trust: Exceptionalism in Asian democracies. The Journal of Politics 68: 259-271. 
Chong, D. and Druckman, J. N. 2007. A theory of framing and opinion formation in competitive elite environments. Journal of Communications 57: 99-118, https://doi.org/10.1111/j.1460-2466.2006.00331.x.

Co, E. E. A. 2005. Challenges to Philippine culture of corruption: Causes, consequences, and change. Paper presented at Redesigning the State? Political Corruption in Development, Policy, and Practice Conference, November. http://publish-pdf.com/ 5f39f29f248143d893cdf643ea406e99/Co.htm (accessed 20 April 2016).

Coley, J. S. 2015. Narrative and frame alignment in social movements: Labor problem novels and the 1929 Gastonia Strike. Social Movements Studies 14: 58-74, https://doi.org/10.1080/14742837.2013.873861.

Druckman, J. N. 2001. The implications of framing effects for citizen competence. Political Behavior 23: 225-256, https://doi.org/10.1023/A:1015006907312.

Gamson, W. A. and Meyer, D. S. 1996. Framing political opportunity. In Comparative perspectives on social movements: Political opportunities, mobilizing structures and cultural framings, ed. McAdam, D., McCarthy, J. D. and Zald, M. N., 275-289. Cambridge: Cambridge University Press, https://doi.org/10.1017/ CBO9780511803987.014.

Gerring, J. and Thacker, S. C. 2004. Political institutions and corruption. The role of unitarianism and parliamentarism. British Journal of Political Science 34: 295330, https://doi.org/10.1017/S0007123404000067.

Goffman, E. 1974. Frame analysis: An essay on the organization of experience. Boston: Northeastern University.

Harrison, L. E. and Huntington, S. P., eds. 2000. Culture matters: How values shape human progress. New York: Basic Books.

Husted, B. W. 1999. Wealth, culture, and corruption. Journal of International Business Studies 30: 339-359, https://doi.org/10.1057/palgrave.jibs.8490073.

Ilagan, B. and Tuazon, B., eds. 2010. Corruptionary: Disyonaryo ng mga salitang korapson sa Pilipinas [A dictionary of Filipino's corruption words]. Pasig City: Anvil Publishing.

Ionescu, L. 2011. Mexico's pervasive culture of corruption. Economics, Management, and Financial Markets 6: 182-187.

Jancsics, D. 2013. Petty corruption in Central and Eastern Europe: The clients' perspective. Crime, Law, and Social Change 60: 319-341, https://doi.org/10.1007/s10611-0139451-0.

Jimenez, E. 2010. Corruption speaks in Metro Manila streets. Paper presented at 13th International Anti-Corruption Conference: Global Transparency: Fighting corruption for a sustainable future, Athens, Greece, 30 October-2 November. http://www.cenpeg.org/pol-study/phil/corruption/CorruptionSpeak\%20in\%20 Metro\%20Manilas\%20Streets\%20-\%20by\%20Evita\%20Jimenez.pdf

Katelaars, P., Walgrave, S. and Wouters, R. 2014. Degree of frame alignment: Comparing organizers and participants' frames in 29 demonstrations in three countries. International Sociology 29: 504-524, https://doi.org/10.1177/0268580914548286.

Kunicova, J. and Ackerman, S. R. 2005. Electoral rules and constitutional structures as constraints on corruption. British Journal of Political Science 35: 573-606, https://doi.org/10.1017/S0007123405000311. 
Lambert-Mogiliansky, A., Majumdan, M. and Radner, R. 2007. Strategic analysis of petty corruption: Entrepreneurs and bureaucrats. Journal of Development Economics 83:351-367, https://doi.org/10.1016/j.jdeveco.2006.06.002.

Landes, D. 2000. Culture makes almost all the difference. In Culture matters: How values shape human progress, ed. Harrison, L. E. and Huntington, S. P., 2-13. New York: Basic Books.

Lederman, D., Loayza, N. V. and Soares, R. R. 2005. Accountability and corruption: Political institutions matter. Economics and Politics 17: 1-35, https://doi.org/10.1111/j.14680343.2005.00145.x.

Lowndes, V. 2010. The institutional approach. In Theory and methods in political science, ed. Marsh, D. and Stoker, G., 60-79. London: Palgrave and Macmillan.

Nolasco, L. Sevillano, K. and Regala, A. 2014. Street based corruption in the Philippines: Motives, ethical considerations and organizational context. Journal of Interdisciplinary Economics 26: 145-160, https://doi.org/10.1177/ 0260107914540828.

Nieuwbeerta, P., De Geest, G. and Siegers, J. 2003. Street-level corruption in industrialized and developing countries. European Societies 5: 139-165, https://doi.org/10.1080/ 1461669032000072265.

Parsons, C. 2010. Constructivism and interpretive theory. In Theory and methods in political science, ed., Marsh, D. and Stoker, G., 80-98. London: Palgrave and Macmillan.

Quah, J. S. T. 2010. Curbing corruption in the Philippines: Is this an impossible dream? Philippine Journal of Public Administration 54:1-43.

Rodis, R. 2015. Is the Philippines really the most corrupt country in Asia? Philippine Daily Inquirer, 16 September (accessed 24 June 2016).

Rushton, S. 2011. Corruption and development: The international anti-corruption movement and anti-corruptionism in India. Cork Online Review, http://corkonlinelawreview. com/editions/2011/03/Sophie-Rushton.pdf (accessed 30 March 2016).

Sanpei, Y. and Aoyagi-Usui, M. 2009. Mass media coverage, its influence on public awareness of climate change issues and implications for Japan's national campaign to reduce greenhouse gas emissions. Global Environmental Change 19: 203-212, https://doi.org/10.1016/j.gloenvcha.2008.10.005.

Scheufele, D. A. 1999. Framing as a theory of media effects. Journal of Communication 49:103-122, https://doi.org/10.1111/j.1460-2466.1999.tb02784.x.

Shleifer, A. and Vishny, R. W. 1993. Corruption. The Quarterly Journal of Economics 108:599-617, https://doi.org/10.2307/2118402.

Snow, D. A., Rochford Jr., E. B., Worden, S. K. and Benford, R. D. 1986. Frame alignment processes and movement participation. American Sociological Review 51: 464-481, https://doi.org/10.2307/2095581.

Soleim, A. and Bontis, N. 2009. The relationship between culture and corruption: A cross national-study. Journal of Intellectual Capital 10: 165-184, https://doi. org/10.1108/14691930910922978.

Transparency and Accountability Network. 2011. Corruption and anti-corruption in the Philippines. Paper presented for GTZ, Philippines.

Treisman, D. 2007. What have we learned about the causes of corruption from ten years of cross-national empirical research. Annual Review of Political Science 10: 211-244, https://doi.org/10.1146/annurev.polisci.10.081205.095418. 
Varela, A. 2003. The culture perspective in organization theory: Relevance to Philippine public administration. In Public Administration in the Philippines: A reader, ed. Bautista, V. et al., 438-472. Diliman, Quezon City: UP NCPAG.

United Nations Convention Against Corruption. 2004. United Nations Office on drugs and crime. https://www.unodc.org/documents/brussels/UN_Convention_Against_ Corruption.pdf (accessed 15 May 2016).

The World Bank. 2015. Helping countries combat corruption: The role of the World Bank. The World Bank, http:/www1.worldbank.org/publicsector/anticorrupt/corruptn/ cor02.htm (accessed 24 August 2015).

Yadav, V. 2012. Legislative institutions and corruption in developing country democracies. Comparative Political Science Studies. 45: 1027-1058, https://doi. org/10.1177/0010414011428596.

Zhan, J. V. 2012. Filling the gap of formal institutions: The effects of Guanxi network on corruption in reform-era China. Crime, Law, and Social Change 58: 93-109, https://doi.org/10.1007/s10611-012-9379-9. 
